\title{
Characteristics and chemical composition of Quails, Coturnix japonica, reared in
} cages

Odafe Shalome, G. and Uwadiae, T. I.

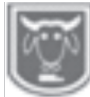

Abstract
Agrofoods and Bioresourses Technology Laboratory, Dept. Animal Science, Univ. of Benin, Benin-City, Nig.

Corresponding author: gideon.odafe-shalome@uniben.edu.ng; $+234(0) 8181303319$

Matured quails were examined for their physical and chemical characteristics. Body length values ranged from 16.4 to $19.0 \mathrm{~cm}$. Longitudinal circumference measured from $30.0-36.3$ $\mathrm{cm}$; latitude circumference ranged between $21.0-27.0 \mathrm{~cm}$. Height of birds ranged from 10.0 - $11.0 \mathrm{~cm}$; neck length measured between 4.0 and $6.3 \mathrm{~cm}$; and limb length varied from 3.0 $3.2 \mathrm{~cm}$. Live weight measurements of the birds ranged from $0.35-0.37 \mathrm{~kg}$, while slaughter weight was $0.32-0.36 \mathrm{~kg}$ carcass weight ranged from $0.31-0.35 \mathrm{~kg}$ while dressed weight was 0.17 - $0.18 \mathrm{~kg}$. Carcass percentage ranged from 91.5 - 95.4 while dressing percentage was 49.4 - 51.6. Crude protein levels were high ranging from $28.94 \%$ to $34.20 \%$; ether extract 14.09 - $17.02 \%$ while ash content was from 0.88 to $0.94 \%$. Quail meat had firm texture, sweet smelling odor and slightly dark in color. It is recommended increasing the production of quails in order to increase animal protein supply and consumption in Nigeria is highly recommended.

Keywords: Quails, body measurement, carcass characteristics, chemical composition.

Des Caractéristiques et la composition chimique des cailles, Coturnix japonica, élevées en

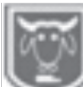

cages

\section{Résumé}

Les cailles mûres ont été examinées pour leurs caractéristiques physiques et chimiques. Les valeurs de longueur corporelle variaient de 16,4 à 19,0 cm. Circonférence longitudinale mesurée de 30,0 à 36,3 $\mathrm{cm}$; la circonférence de la latitude variait entre 21,0 et $27,0 \mathrm{~cm}$. La taille des oiseaux variait de 10,0 à $11,0 \mathrm{~cm}$; longueur du cou mesurée entre 4,0 et $6,3 \mathrm{~cm}$; et la longueur des membres variait de 3,0 à 3,2 $\mathrm{cm}$. Le poids vif des oiseaux variait de 0,35 à $0,37 \mathrm{~kg}$, tandis que le poids à l'abattage était de 0,32 à $0,36 \mathrm{~kg}$, le poids de la carcasse variait de 0,31 à $0,35 \mathrm{~kg}$ tandis que le poids habillé était de 0,17 à 0,18 $\mathrm{kg}$. Le pourcentage de carcasse variait de 91,5 à 95,4 tandis que le pourcentage d'habillage était de 49,4 à 51,6. Les niveaux de protéines brutes étaient élevés allant de 28,94\% à 34,20\%; extrait d'éther 14,09-17,02\% tandis que la teneur en cendres était de 0,88 à 0,94\%. La viande de caille avait une texture ferme, une odeur douce et une couleur légèrement foncée. Il est recommandé d'augmenter la production de cailles afin d'augmenter l'approvisionnement en protéines animales et la consommation au Nigeria est fortement recommandée.

Mots clés: cailles, mesure du corps, caractéristiques de la carcasse, composition chimique.

\section{Introduction}

In Nigeria the level of animal protein consumed by an individual is about $10 \mathrm{~g} /$ day. This is grossly inadequate when compared to the recommended level required daily for optimum growth $55 \mathrm{~g} /$ day (FAO, 2007). As the human population in the country is steadily increasing, one of the critical needs therefore, is to expand the national food basket; particularly animal protein supply. It has been proposed that one of the approaches towards achieving this is to explore various animal species having potentials for domestication and consumption (Olomu, 2011). In this regard the poultry industry appears to provide a 


\section{Characteristics and chemical composition of Quails, Coturnix japonica}

variety of species for this purpose. Poultry include the domestic fowl, guinea fowl, turkey, ducks and geese, which produce meat and eggs. There is also the quail, a lesser known poultry species which like the chicken, is most commonly bred for human consumption. Quail meat has been known from historic times; whereas in Nigeria it is a recent development to consider the quail as a having a high potential in commercial poultry (Mizutani, 2003; Randall and Bolla, 2008). There is increasing demand for quail meat and eggs due to the assumption that it is useful, and can be exploited therapeutically in the prevention and management of degenerative health conditions such as obesity and cancer (Schmidth et al, 2000; Mielnik et al, 2002; Wolpert et al, 2008; WHO, 2008). In addition to the potential health benefits is the increasing awareness that quail enterprise also has a high economic benefit (Odafe and Onovuvwe, 2020). Hence the birds are being reared under intensive management at Songhai-Delta farms, to demonstrate husbandry techniques for quail production, and to encourage quail farming. This study thus evaluated carcass characteristics and nutritive value of quail meat produced at Songhai Delta, and assessed the meat.

\section{Materials and methods Location of study}

The quail birds used in this study were raised under intensive management at Songhai Delta Demonstration Farms, Sapele. The birds were transported to location where measurements were undertaken in the University of Benin Farm project, Benin-City, which is about $60 \mathrm{~km}$ away from Sapele town. Both cities lie within same bioclimatic zone, between latitude $5^{\circ} 44^{\prime \prime} \mathrm{N}$ and $7^{\circ} 34^{\prime} \mathrm{N}$ and between longitude $6^{\circ} 04^{\prime} \mathrm{E}$ and $7^{\circ} 25^{\prime} \mathrm{E}$. The vegetation stretching over the two cities is predominantly rain forest. The average daily temperature range is $24-35^{\circ} \mathrm{C}$; rainfall: $2500-2650 \mathrm{~mm}$; and relative humidity $(\mathrm{RH})$ of $85-95 \%$.

\section{Experimental work}

\section{Anthropometric measurements}

Twenty (20) matured birds aged about 2.5years, were sampled from the quail unit. Morphological features were examined according to procedure described by Maina (2000) and Dana et al (2010). Measurements were taken for live weight, using electronic balance; and sizes of body parts, using a centimeter tape. The mean values for the different measurements average weight of birds, height of birds, body length, body circumference (longitudinal and latitudinal), neck length and circumference, wing length and limb length, were computed and recorded.

\section{Carcass measurements}

The method described by Odunsi et al (1999) was followed. Birds were slaughtered by cutting the neck with a sharp knife and letting the bird to bleed. Following bleeding slaughter weight (SW) was taken for each carcass. Then the feathers, head, nails and cornified epidermis around the limbs, representing the external offals, were removed to obtain defeathered carcass, which was then weighed and recorded as carcass weight $(\mathrm{CW})$. Defeathering was performed by immersing undressed carcass in hot water for about 3 minutes, which made it easy to remove the feathers by hand-plucking. The defeathered carcass was eviscerated and dressed, by cutting open the abdomen to remove the internal (visceral) organs, representing the internal offals. Eviscerated organs included the GIT, liver, kidneys, lungs and associated tissues. These were identified and weighed separately to determine the relative organ weight of each. Then dressed carcass was weighed and recorded as eviscerated / dressed weight (DW).

The carcass characteristics of quail bird were thus evaluated by simple 
calculations:-

Carcass percentage $(\%) \quad=$ Carcass

Weight/Live weight x 100

Dressing percentage $(\%) \quad=$ Dressed

Weight/Live weight x 100

Relative organ weight $(\%)=$ Organ

Weight/Live weight x 100

\section{Chemical analyses}

Each dressed carcass was oven dried to constant weight and prepared for chemical analyses. Proximate analysis was performed for moisture content, ash, crude protein, fat, and total soluble carbohydrate in quail meat. The conventional analytical techniques were used, in line with recommendation (AOAC, 2010).

\section{Statistical analysis}

The data was analyzed using SAS (System
Analysis Software) and means were separated by species and compared by Duncan's Multiple Range Test (Duncan, 2000).

\section{Results \\ Body measurement of quails}

The quail birds measured $16.4-19.0 \mathrm{~cm}$ in body length (Table 1). Body circumference ranged from $30.0-36.3 \mathrm{~cm}$ for the longitudinal, and $21.0-27.0 \mathrm{~cm}$ for latitude with averages of $17.68 \mathrm{~cm}$ and $33.08 \mathrm{~cm}$ respectively. The average height of the birds was $10.2 \mathrm{~cm}$. Neck length ranged from $4.0-6.3 \mathrm{~cm}$; and neck circumference was averagely $5.80 \mathrm{~cm}$. Wing length varied between 9.0 and $10.0 \mathrm{~cm}$, while length of the limbs was $3.0-3.2 \mathrm{~cm}$ (Table 1).

Table 1: Meanof Body measurementof quail birst-length and circumferencen(i)

\begin{tabular}{lllllllll}
\hline *Sample Group & BL & LgC & LaC & HT & NL & NC & WL & LL \\
\hline G1 Quails & 17.0 & 32.0 & 24.0 & 10.0 & 4.0 & 5.0 & 9.1 & 3.0 \\
G2Quails & 19.0 & 36.3 & 21.0 & 10.0 & 5.0 & 6.0 & 9.0 & 3.2 \\
G3 Quails & 18.2 & 34.0 & 22.4 & 10.0 & 4.4 & 5.0 & 9.0 & 3.0 \\
G4 Qualis & 17.8 & 33.1 & 25.4 & 11.0 & 6.3 & 7.0 & 10.0 & 3.2 \\
G5 Quails & 16.4 & 33.0 & 27.0 & 10.0 & 5.0 & 6.0 & 9.2 & 3.0 \\
MeanSD & 17.68 & 33.08 & 23.96 & 10.2 & 4.94 & 5.8 & 9.24 & 3.1
\end{tabular}

*values represent mean of measurements for sample grou 65 , Cehch made up of four birds.

KEY: BLbody length, Lgtongitudinal circumference, Ehatitudinal circumference, -heilight, Nłneck length,

NC-neck circumference, Wwing length, L-limb length

Carcass measurement of quails

The average live weight of a matured quail is $0.37 \mathrm{~kg}$ (Table2). Mean live weight (LW) values ranged from 0.35 to $0.37 \mathrm{~kg}$ while mean slaughter weight (SW) was 0.32 -
$0.36 \mathrm{~kg}$; defeathered carcass weight (CW) ranges from $0.31-0.35 \mathrm{~kg}$ while eviscerated or dressed weight (DW) was $0.17-0.18 \mathrm{~kg}$ carcass percentage ranges from $91.5-95.4$ $\mathrm{kg}$ while dressing percentage was 49.4 $51.6 \mathrm{~kg}$.

Table2: MeanLive weight (kg) and carcass measurements of quaisbird

\begin{tabular}{lllllll}
$\begin{array}{l}\text { *Sample } \\
\text { groups }\end{array}$ & $\begin{array}{l}\text { Live } \\
\text { weight }\end{array}$ & $\begin{array}{l}\text { Slaughter } \\
\text { weight }\end{array}$ & $\begin{array}{l}\text { Carcass } \\
\text { weight }\end{array}$ & $\begin{array}{l}\text { Dressed } \\
\text { weight }\end{array}$ & $\begin{array}{l}\text { Carcass } \\
\%\end{array}$ & $\begin{array}{l}\text { Dressing } \\
\%\end{array}$ \\
\hline QG1 & 0.345 & 0.325 & 0.316 & 0.174 & 91.59 & 50.43 \\
QG2 & 0.362 & 0.349 & 0.332 & 0.179 & 91.71 & 49.45 \\
QG3 & 0.366 & 0.353 & 0.347 & 0.188 & 94.12 & 52.08 \\
QG4 & 0.368 & 0.360 & 0.351 & 0.186 & 95.38 & 50.54 \\
QG5 & 0.372 & 0.361 & 0.355 & 0.165 & 95.43 & 51.61 \\
Mean SD & 0.366 & 0.350 & 0.340 & 0.178 & 93.65 & 50.82 \\
\hline
\end{tabular}

*values represent mean for sample groups, -QG1 QG5, each made up of four birds. 


\section{Characteristics and chemical composition of Quails, Coturnix japonica}

Table 3: Proximate composition of quail meat (g/100gDm

\begin{tabular}{lllllll}
\hline & QG1 & QG2 & QG3 & QG4 & QG5 & Mean \\
\hline CP & 29.38 & 28.94 & 32.40 & 30.60 & 34.20 & 31.10 \\
Fat & 14.60 & 16.80 & 14.80 & 17.02 & 14.09 & 12.64 \\
Ash & 0.92 & 0.90 & 0.89 & 0.88 & 0.94 & 0.91 \\
NFE & 55.10 & 53.36 & 51.91 & 51.50 & 50.77 & 52.53 \\
\hline
\end{tabular}

*values represent mean of replicate determinations for each group of birds

\section{Discussion}

\section{Morphology and carcass characteristics of quail}

Quails were evaluated for body and carcass measurements and their proximate compositions (Table 4). The birds are small in size and have physical and behavioral characteristics which are similar to those reported for domestic fowl, chicken and pheasants (March, 1971; Hall, 2012). Young quails raised at Songhai Delta farms recorded live weight values which ranged between 0.15 and $0.172 \mathrm{~kg}$, with an average of $0.163 \mathrm{~kg}$; while the adult quail bird weighed averagely $0.37 \mathrm{~kg}(370 \mathrm{~g})$ which corresponded with records in published data (Akpan and Nsa, 2009; Oluwatomi, 2010; Ortlieb, 2013). Length of head ranged from $3.3-4.7 \mathrm{~cm}$ with mean of $3.9 \mathrm{~cm}$; length of neck ranged from $4-6.3 \mathrm{~cm}$ with mean of $4.8 \mathrm{~cm}$; length of wings ranged from 9.0$10.0 \mathrm{~cm}$ with mean of $9.4 \mathrm{~cm}$; length of tail measured from $10.0-12.0 \mathrm{~cm}$ with mean value of $10.7 \mathrm{~cm}$. Length of drum stick ranged in values from $9.0-12.5 \mathrm{~cm}$ with mean of $10.5 \mathrm{~cm}$; and length of shank ranged between $3.0-3.3 \mathrm{~cm}$ with mean value of $3.1 \mathrm{~cm}$. The least height measured for the birds was $10 \mathrm{~cm}$ while the mean height was $10.6 \mathrm{~cm}$.

Carcass evaluation results indicate that dressing percentage of quail birds averaged $50.82 \%$. This means that the edible meat and the offals were relatively equal in proportion; and much waste could be generated from quail processing. Nonetheless, the quail meat examined showed a sweet smelling odor, slightly dark in color, firm in texture, and contained the high crude protein level of between 28.0 $35.0 \%$. The lean:bone ratio was not determined; however there are indications that quail bones are of the soft type (LeBilhan-Duval, 2008); hence consumable along with the lean. This implies a high supply of calcium in diet containing quail meat as source of protein.

\section{Chemical composition of quail meat}

Average crude protein content of $31.10 \%$ measured for quail meat in this study, was comparatively higher than the $19.6 \%$ required of a protein source by USDA (1999). The value is also higher than the crude protein levels of $19.20 \%$ published for chicken meat, $19.98 \%$ for guinea fowl and $22.20 \%$ in turkey (Olomu, 2011). The average fat content measured for quail in this study, was $12.64 \%$, (Table 2), a value which is higher than USDA (1999) record of $12.1 \%$ for quail meat. However, these results indicate quail is not a fatty meat compared to high fat meat such as duck $(39.3 \%$ fat), pork $(31.01 \%)$, guinea fowl $(30.46 \%)$ indigenous fowl $(26.62 \%)$, and old layer 26.32\% (Olomu, 2005; 2011). This confirms the assertion quail offers a low cholesterol meat (Mielnik et al., 2002); and that is the reason it is highly recommended to the elderly, and to obese persons (Schmidth et al., 2000; WHO, 2008; Wolpert et al 2008). The ash content of quail meat examined in this study was $0.91 \%$ (Table 3 ); and this also corresponded to reported values for beef $(1.10 \%)$ and turkey $(0.91 \%)$ - (USDA, I995; Olomu, 2011).

Thus, the findings of this study seem to support previous assertions that the quail 
meat has a superior nutritive value among poultry and livestock species (Hemid et al 2010; Levy, 2018). Among the indices of meat quality are firmness, toughness/tenderness, color, texture and teasability (Ikeme, 1990). Generally, the meat of poultry species is classified as white meat (Ikeme, 1990; Mielnik et al., 2002). Based on its brown color, that classification may not hold for quail meat, subject to expert debate. Sensory evaluation was not undertaken in this study; but observations and reports elsewhere indicate that quail meat is firm, mildly tough and appear darker than chicken meat after cooking These are specific qualities that are appealing to marketers and consumers of poultry products in Nigeria and elsewhere (Okubanjo, 1986; Ikeme, 1990; Mielnik et $a l .$, 2002). Nigeria is faced with the problem of inadequate protein supplies and consumption. The poultry population in Nigeria was estimated at 119million (NPC, 2004). In comparison human population is over 200 million persons (NPC, 2004). Quail meat is already being consumed in Nigeria. Therefore, farmers need be encouraged to increase their interest and investment in the production of quails as essential components of the livestock sector. Hence, much is required by way of policies, financing and strategies to expand the national food basket with lesser known poultry species such as the quail. The small size of the bird compared to conventional poultry species may not be encouraging to farmers; but when the productivity of the bird is considered, including the early maturity, high rate of egg and meet production, inexpensive infrastructural and husbandry requirements quick turnover and early returns to investment, and the increasing demand for quail and its products, in addition to the high nutritive and health value (Odafe and Onovuvwe, 2020), it behooves on all stake holders to see the quail as a food security bird useful to combat protein malnutrition and fill the gap opened by the inadequate protein supplies in developing countries.

\section{Conclusion and recommendation}

This study has shown that the quail is a small size bird with brown plumage. The meat is protein rich containing $31.10 \%$ crude protein, which is superior to chicken and turkey meat, and to lamb and beef. Ash content that was measured was appreciably high. Functionally, quail meat is firm, has a delightful aroma, sweet smell, slightly brown color, and has good texture and teasability; but unlike the chicken, it may not be described as white meat because it is dark in color. This means that quail meat has attributes and nutritive value that make it very promising. Thus this study recommends that in order to increase the production and supply of animal protein for the Nigerian populace commercial quail production need be considered in addition to other poultry species in national food policy.

\section{References}

Akpan, I. A. and Nsa, E. E. 2009. Growth performance of growing Japanese quail Coturnix coturnix japonica, fed diets containing different crude protein levels. Proc. 14th Ann. conf. Anim Sci Assoc of Nigeria (ASAN).14th-17th Sept. LAUTECH, Ogbomoso, Nigeria, pp553-555.

AOAC, 2010. Association of Analytical Chemists, Official methods of Analysis, $20^{\text {th }}$ edition, Washington, $D C$, USA.

Dana, N., Dessiea, T., van der Waaija, L. H. and van Arendon, J. A. M. 2010. Morphological features of indigenous chicken populations of Ethiopia. Animal Genetic Res. Info, 46: 11-23.

FAO, 2007. The state of the world's animal 


\section{Characteristics and chemical composition of Quails, Coturnix japonica}

genetic resource for food and agriculture. Commission on genetic resources for food and agriculture, FAO Rome a CD-ROM.

Hall, G. 2012. Brown Quail and its Management. 2012-05, Brown quail and its management.pdf.

Hemid, A. F. A., Abd El-Gawad, A. K., ElWardany, I., El-Daly, I. F. and AbdEl-Azeem, N. A. 2010. Alleviating Effects of some Environmental stress factors on productive performance in Japanese quail 2. Laying performance World Journal of Agric. Sciences 6(5), 517-524.

Ikeme, A. I. 1990. marketing of meat in Nigeria: meat science and technology $1^{\text {st }}$ edition Africa feb publishers Ltd, Onitsha Nigeria.

Le Bihan-Duval, E., Debut, M., Berri, C. M., Sellier, N., Sante- Lhoutellier, V., Jego, Y. and Beaumont, C. 2008. Chicken meat quality: Genetic variability and relationship with growth and muscle characteristics. BMC Genet.9:53.

Marsh, A.F.1971. Quail Manual, 7th edn. Marsh Farms, Garden Grove, California, 52 pp Maina J.O. (2000) Morphological and molecular characterization of Kenyan indigenous chickens. $P h D$ thesis, Egerton University, Njoro, Kenya.

Mizutani, M. 2003. The Japanese Quail. Laboratory Animal Research Station. Nippon Institute for Biological Science, Kobuchizawa, $\mathrm{Y}$ a $\mathrm{m}$ a $\mathrm{n}$ a $\mathrm{s} \mathrm{h} \mathrm{i} \mathrm{J} \mathrm{a} \mathrm{p}$ a $\mathrm{n}$. (http://www.angrin.tlri.Rov.tw/ape c 2Q03/Chapter5JPQuail.pdf): Retrieved December 15,2009.

Moreki, J. C., Dikeme, R. and Poroga, B. 2010. The role of village poultry in food security and HIV/AIDS mitigation in Chobe District of
Botswana. Livestock Research for Rural Development.22 Article \#5 ttp://www.1rrd.org/lrrd22/3/more2 2055.htm.

NPC, 2004. National Planning Commission. New Partnership for African development. Comprehensive Agriculture programme, Abuja.

Odunsi, A. A., Farinu, G. O., Akinola, S. O. and Togun, V.A. 1999. Growth, Carcass characteristics and body composition of broiler chicken fed with sunflower (Tithonia diversifolia) forage meal. Tropical Animal Production Investigating 2:205-211

Hemid, A. F. A., Abd El-Gawad, A. K., ElWardany, I., El-Daly, I. F. and AbdEl-Azeem, N. A. 2010. Alleviating Effects of some Environmental stress Factors on productive performance in Japanese quail 2. Laying performance World Journal of Agricultural Sciences 6 (5), 517524.

Okunbanjo, A. 1986. Factors Affecting Meat buying practices in subsegment of urban Nigerian Populace. Seminar on Nigerian Food Culture. Institute of African Studies, Univ. of Ibadan

Olomu, J. M. 2011. Monogastric Animal Nutrition. Principles and practice, St.Jackson publication, BeninCity, Nigeria.

Oluwatomi, O. 2010. Raising Quails: www.tnbune.com.ng/index.phpAve alth

Ortlieb, G. 2013. Raising Coturnix Quail.www. how to raise quail.com/coturnix quail.

Podems, M. 1975. Coturnix Quail Challenges the Chicken. Organic Gardening and Farming, June: 3641. 


\section{Odafe Shalome and Uwadiae}

Randall, M. and Bolla, G. 2008. Raising Japanese Quail. State of New South Wales, Department of Primary Industies. Prime Fact 602, 2nd Edition.

Rankling, F. W., Artin, A., Lison, G. M., Artin, D. and Nnabelle, M. A. 1998. Quail: An egg and meat production system.
USDA, 1999. Nutrient Database for student reference. Release 13, USDA, United State Dept. of Agriculture, Washington D.C.

Received: $19^{\text {th }}$ September, 2020

Accepted: $5^{\text {th }}$ January, 2021 